\title{
Consolidation of the Victorian Marriage Tradition in Hardy's Jude the Obscure
}

\author{
Parvin Ghasemi* \\ Masood Keshavarz *
}

\begin{abstract}
Jude the Obscure by Thomas Hardy has always been considered a novel in which the concept of the traditional Victorian marriage is severely criticized through various tones. New Historicism and Cultural Materialism are methodological approaches that provide us with a different interpretation of this novel. Therefore, on the basis of these "reading practices," as Greenblatt calls them, the researchers attempt to offer another reading of this novel. The present research concludes that Jude the Obscure at first presents an explicit, reproachful treatment of the conventional Victorian marriage but at the end it reinforces this type of marriage by repressing the characters whose views are at odds with the dominant views of the society. In other words, through marginalizing its own major characters as "the others", Jude the Obscure consolidates the dominant discourse of the Victorian society about "marriage".
\end{abstract}

Keywords: Victorian marriage, new historicism, cultural materialism, consolidation, and discourse

\footnotetext{
* Corresponding author: Parvin Ghasemi, Department of Foreign Languages and Linguistics, Shiraz University, Iran, e-mail: pghasemi2000@yahoo.com

* Corresponding author: Masood Keshavarz, Department of Foreign Languages and Linguistics, Shiraz University, Iran, e-mail: keshavarz368@yahoo.com
} 
"Marriage", as a social institution, has always been considered one of the major themes around which a good number of Victorian novels such as Jude the Obscure revolve. It is believed by many critics that the presentation of "marriage" in this novel has been performed through various literary tones including irony, diatribe, sarcasm, satire or direct criticism. Indeed, the bulk of articles and books about Thomas Hardy and his treatment of "marriage" in Jude the Obscure indicates the critical reception that this novel has enjoyed in this regard.

Norman Vance in an illuminating introduction to Wordsworth Classics edition of the book asserts:

So at one level this can be seen as a novel of social protest and commentators have laid varying emphasis on three connected social themes in the novel: educational and social disadvantage, marriage and divorce, and the position of women. (VII)

Patricia Ingham in her introduction to the Oxford edition of the novel observes:

Hardy denied the novel was an attack on marriage laws and was right to discard this superficial reading; but his assertion in the 1912 postscript that 'the general drift' in relation to such laws was that 'the civil law should only be the enunciation of the law of nature' is more problematic.(XVII).

Lance St John Butler also writes," The man who fell in love with Emma Gifford lives to regret his marriage, to write bitterly against marriage as an institution"(13). Aeron Matz believes that

"The destructive energy of Jude the Obscure is aimed in many directions: at the oppressive Victorian strictures of marriage, at the exclusion of the universities, at a society in which the lot of the poor is wretched" (542)

\section{Moreover, Lionel Stevenson mentions that Havelock Ellis's}

"Concerning Jude the Obscure" was among the first to defend its challenge...to idealized Victorian marriage and to Victorian ideals of social perfectibility" (384).

Raymond Williams asserts:

One of the most immediate effects of mobility, within a structure itself changing, is the difficult nature of the marriage choice. This situation keeps recurring in terms which are at once personal and social:...Jude [choosing] between Arabella and Sue. The specific class element and the effects upon this of an insecure economy, are parts of the personal 
choice....And here significantly the false marriage(with which Hardy is so regularly and deeply concerned)can take place either way.(371)

In addition, Richard Gill in his discussion of the English novel dedicates a headline called "marriage" to Jude the Obscure and by quoting Sue's letter to Jude emphasizes "But later in the $19^{\text {th }}$ century, there are indications that marriage might not be so valued" (399). Besides, A. Abjadian in his comments on the Victorian novel mentions that "Jude the Obscure is about the inevitable frustration of the human condition, not an attack against the marriage law or the refusal of Oxford colleges to admit rustics" (413). Karen Lawrence also believes, "Unlike many nineteenth century novels, which picture marriage as the final fulfillment...Hardy's turn of the century novel expresses deep pessimism about the institution of marriage"( 370). Finally, Maria Frawley states that "Much of his [Hardy's] subject matter-sexual victimization.... and unhappy marriage in Jude the Obscure-exposed him to the wrath of reviewers bent on measuring his fiction against the standards of circulating -library morality" (444).

The list of quotations in which Thomas Hardy's criticism of conventional marriage is discussed can be much longer than this. However, the objective of this paper is to show if there is any other possible reading of Jude the Obscure and its depiction of the concept of marriage. Except for Abjadian, all the above mentioned critics and so many other ones maintain the idea that Jude the Obscure challenges the orthodox system of marriage in its Victorian sense. In other words, they claim that it is a "subversive" text, as far as the conventional marriage is concerned. This paper, however, asserts that reading the novel as $\mathrm{s}$ subversive text does not refute the possibility of its being read as a "consolidatory" one. Such a possibility is provided for us by the tenets of New Historicism and Cultural Materialism. These critical approaches, Greenblat says, "should be viewed as a reading practice" (Bressler 216). Therefore, the researchers attempt to present a re-reading of this seemingly subversive text and to point to the parts in which the opportunity of reading it as a consolidatory text is at our disposal.

"Consolidation," according to New Historicism, refers to ideological means whereby a dominant order seeks to perpetuate itself 
while subversion is the discovery of the means to resist it and subvert the order. As David Lodge believes, "To be aware of the historical basis of all discourses is inevitably also to become conversant with the dialectical way a significant text might mirror codes as well as mould and often resist them" (495).

Thus, it can be reasonably surmised that Jude the Obscure not only "resists the dominant code" (the Victorian concept of marriage) but also "mirrors" and "moulds" and consolidates it. In order to clarify what we mean by "consolidation of the dominant code," we can investigate a number of relevant questions about this novel and its writer. The first question is about Hardy himself: Does Hardy take sides with his own fictional characters (Jude and Sue) or does he support the conventional side? It is already known that Sue and Jude's ideas do not conform to the dominant definition of marriage in the Victorian era. However, at the end of the novel, we have Sue define herself as "a poor wicked woman who is trying to mend"(319; pt.6, ch.4) and we observe Jude musing, "What does it matter what my opinions are, a wretched like me!" (340; pt.6, ch.8).

These two shattered characters are created by Thomas Hardy in his exploration into women's attempts at self-discovery. They used to be the paragons "of the highest and purest loves that ever existed between man and woman"(314; pt.6, ch.3). One may ask oneself if the novel could have had a different ending. The one suggested by Jude, for example, could have been an option, "Let us then shake off our mistakes, and run away together!"(344; pt.6. ch.8) .

Obviously enough, it is Hardy who seems to have already decided about the ending of his novel. According to Nemesvari, In Thomas Hardy: A Biography, Michael Millgate notes that, "Jude seems, in manuscript, to have been first called Jack...But Hardy had on his shelves a copy of Charlotte M. Young's then standard History of Christian Names ,and in finally deciding to call his hero Jude he was well aware of the ill omen attaching to the name" ( 54-5). In other words, Hardy's choice of his characters' fate seems to be somehow predestined. This predestination of Jude and consequently that of Sue confirms the hypothesis of this paper that if one can try to give the novel a fresh re-r 
reading, the thematic outcome of Jude the Obscure might be interpreted differently as well.

In the Victorian atmosphere of the novel, Jude and Sue form minority. Their ideas about marriage and religion are in open opposition to the dominant ideas of their era. To put it differently, Jude and Sue are the marginalized individuals; they are the "others". Greenblat in Renaissance Self Fashioningstates:

We define our identities always in relation to what we are not, and therefore, what we are not "Sue and Jude" must be demonized and objectified as "others". The mad, the unruly and the alien are internalized "others" which help us to consolidate our identities; their existence is allowed only as evidence of the rightness of established order. (Selden 161)

Accordingly, when Sue confesses that she is "a poor wicked woman who is trying to mend" and Jude emphasizes that his opinions do not matter, they are condemning their own "otherness" and in this way they confirm what they are not. That is, the dominant discourse which eulogizes the "conventional marriage" is verified, even if , indirectly by the characters who are supposedly against this kind of marriage.

Thus, it can be argued that even though Jude the Obscure has always been discussed as a text against the authority of the Victorian marriage (a subversive text), it can also be viewed by the dominant discourse to confirm its own righteousness. In other words, even if Hardy aims to criticize the conventional institution of marriage, the outcome of his novel is not necessarily limited to this single interpretation. As Binion says, "Even a work of creative genius may convey a message other than its author intended. To tease arguments out of fiction can be tricky" (679). That is, although Hardy, as it is generally believed, has meant to criticize the status quo of his time, his text may not merely convey criticism. It is Jude who says, "...the time was not ripe for us. Our ideas were fifty years too soon to be any good to us. And so the resistance they met with brought reaction in her, and recklessness and ruin to me!"(355;pt.6,ch.10).

It seems that Hardy is conveying something different from what we have already read in the critics' notions mentioned above. Is he not 
implicitly encouraging the readers to surrender to the status quo because "the time [is] not ripe" yet"? Widdowson believes,

Thomas Hardy has been produced and reproduced in history in a certain guise and for certain purposes by the dominant cultural apparatuses-not of course ,consciously or conspiratorially, but in the silent and naturalizing process which tirelessly confront us with the images of human life and experience we genuinely believe to be true. (6) Therefore, we can conclude that the "Hardy" we have known as a critic of "institutional marriage" is not the only "Hardy" we may find in Jude the Obscure. It is evident that the tragic fate of Sue and Jude can be the example to be used to convince the Victorian readers that there is no chance of happiness for those who choose an unconventional marital state. According to Bertens,

In this Foucauldian context, power works through discourses and, like ideology, gives the subject the impression that to comply with its dictates is the natural thing to do and thus a free autonomous decision. It does not need to appear repressive because it effectively turns the subject[the readers of the novel] into its own watchdog.

Hence, Widdowson 's idea seems to be very to the point when he asserts: "Modern Hardy criticism, then generally reproduces a 'Thomas Hardy' whose lines were drawn early" (43). That is, modern criticism has always told us about the function of Hardy as a critic of issues such as education, Christianity, marriage, women's position, etc. It has already been shown that by sacrificing his pioneer, avant-garde fictional characters, Thomas Hardy can be potentially and practically, though unconsciously, consolidating the conventional values.

In other words, Hardy, the Victorian individual, is an example for what Louis Montrose has defined, "I have a complex and substantial stake in sustaining and reproducing the very institutions whose operations I wish to call into question" (Bertens 182). Actually what finally happens to the two major characters of the novel and the fact that Hardy himself is a Victorian author (subject) affirms what Bertens states:

Subjects cannot transcend their own time but live and work within the horizons of a culture constructed by ideology, by discourses. The ideological constructions that authors live in, and have internalized 
,inevitably become part of their work, which is therefore always political and always a vehicle for power. (185)

In other words, Hardy's decision in depicting Jude and Sue as the "wretched" man and the "poor woman" somehow implies that his pioneer characters' daring personalities are finally influenced and fated by the author's Victorian "internalized" conventions. It has already been mentioned that Jude and Sue represent the resisting discourse within the society. It should be added that according to Foucault, this resistance is an inward necessity for the dominant system to consolidate its own discourse.

Based on the necessity that Foucault believes in and considering what we have already mentioned, it is justifiable to say that on the one hand Hardy intentionally criticizes the conventional marriage .On the other hand, Jude the Obscure implicitly supports such an institution of marriage. The Victorian period is not the suitable time for the unconventional, marginal discourses of marriage. As Jude says, "Our ideas were fifty years too soon"(355; pt.6, ch.10). It is obvious that Hardy is influenced by the dominant discourse of his own time. He has definitely created an intellectual female character (Sue) and a nonconformist male character (Jude), has brought them together through an unconventional unity and finally has left them defeated because the time is not ripe for their ideas yet.

According to Virginia Woolf,

There is always about them [Hardy' s novels] a little blur of unconsciousness...It is as if Hardy himself were not quite aware of what he did, as if his consciousness held more than he could produce, and he left it for his readers to make out his full meaning and to supplement it from their own existence. (174)

It is evident that the Victorian readers' experience combined with the tragic conclusion of Jude the Obscure bring about nothing except social conformity and this conformity is the inevitable impression of the novel on its own contemporary readers even if the impression takes place in their collective unconscious, and argues that Renaissance subversion inevitably plays into the hands of power. In fact, power needs subversion and actively produces it: "subversiveness is the very product of that power and furthers its ends"(Bertens181). 
A New Historical reading of this novel suggest that Jude the Obscure can be considered a text which is potentially capable of being appropriated by the dominant discourse in order to consolidate the conventional concept of marriage. It is significant to remember that Sue "whose intellect was to mine [Jude's] like a star to a benzoline lamp; who saw all my superstitions as cobwebs that she could brush away with a word" (354; pt.6,ch.10) finally returns to Phillotson " trying to mend". It is also Sue who says ,"I am getting as superstitious as a savage!...I am cowed into submission. I have no more fighting strength left; no more enterprise. I am beaten, beaten!...We are made a spectacle unto the world, and to angels, and to men! I am always saying that now"(303; pt.6,ch.3). To all these regretful statements Jude replies, "I feel the same"(304; ibid.).

Critics like Jonathan Dollimore and Catherine Besley argue that the resistance or subversion may indeed be appropriated by authority for its own purpose, but once installed, it can be used against authority as well as used by it" (Fardad 6).Consequently, one can propose that Jude the Obscure like any other text has the potentiality of being appropriated by either the subversive or the supportive discourses of the conventional marriage institution because as Bertens suggests:

Literature does not simply reflect relations of power but actively participates in the consolidation and/or construction of discourses and ideologies...Literature is not simply a product of history, it also actively makes history. (177)

To substantiate this argument, Some of the major questions in cultural poetics can be investigated: "What authorial biographical facts are relevant to the text?"; "What kinds of behavior and models of practice do this work seem to reinforce?" and "Whose freedom of thought or movement might be constrained implicitly or explicitly by this work?" (Bressler226).

In dealing with the first question one can refer to Hardy 's own marriage which was not a happy one but he remained faithful to the vow until his wife passed away. That is, the conformity has already been practiced by Hardy himself. According to Butler, "Their [Hardy and Emma Gifford's] views of the world were utterly opposed...in the 1890s Hardy added an outside staircase to his house, Max Gate in Dorchester, 
so that he could move between his study and the garden without, it was said, encountering Emma"(12).

It is rather noteworthy to mention that while Hardy maintained his own conventional marriage in spite of all the incompatibilities of the couple, he created the characters whose ideas about the Victorian marriage were evidently offensive to the readers. Nemesvari states:

Although he [Hardy] constantly denied it, there is little doubt that parts of Jude the Obscure are autobiographical. Like his protagonist, as a young man Hardy aspired to a university education and possible career as a clergyman, laboriously teaching himself Greek in order to read classical dramatists and the New Testament in the original. (52)

Biographically speaking, while Hardy himself did not try the unconventional marital state and made a rather tremendous effort to preserve his own traditional marriage, in spite of its seemingly undesirable condition, his fictional counterpart (Jude) is allowed to practice an unusual marital affair. The fact that Jude and Sue are brutally defeated in their unconventional relation convinces us that for the second and the third questions posed by cultural materialists, we can find suitable answers. That is to say, the kind of behavior and models of practice that the novel implicitly reinforces are the ones that Hardy himself practiced in his own personal life as a Victorian individual.

In fact, by preserving his unhappy conventional marriage, Hardy escaped the tragic doom of his pioneer fictional characters. It is important to remember Sue's remarks, "For a man and woman to live on intimate terms when one feels as I do is adultery, in any circumstances, however legal"(193;pt.4,ch.3); however, when she tells Jude, "We must conform!"(303;pt.6,ch.3), "I have thought that I am still his wife!"(304;ibid.) and the fact that she returns to Phillotson, may seem somehow confusing for the reader, especially, twenty-first century one! It is, Sue who encourages conformity at the expense of losing their romantic union.

It seems that for his own self, as a real person, and for Sue, as a female intellectual character, Thomas Hardy finally prescribes "adultery" as a classic deadly sin. Moreover, "the freedom of thought and movement" of the marginalized characters (Sue and Jude) are constrained explicitly by this novel. It is worthy to mention Sue's statement again to 
see whose freedom is constrained, "There is no choice. We must conform!...There is no choice. We must" (303;pt.6,ch.3).

Consequently, Jude the Obscure does not solely contain the critical discourse of the conventional marriage, as modern criticism has always claimed. It, rather, presents the possibility of a consolidating narrative in which the institution of conventional marriage is reinforced. In other words, Hardy, though unconsciously, has created a novel in which the nonconformists are marginalized as "the others" and are finally suppressed by the dominant social discourse that has influenced the mentality of a Victorian writer.

According to Barry,

"Discourse is not just a way of speaking or writing, but the whole 'mental set' and ideology which enclose the thinking of all members of a given society. It is not singular and monolithic -there is always a multiplicity of discourses"(154).

Therefore, it is believed that Thomas Hardy, as a member of the Victorian society presents the subject of marriage in Jude the Obscure in a two dimensional discourse. The first level, which is explicit, seems to be a critical approach to the Victorian marriage; the second one, however, the one that is more implicitly provided, is a consolidatory discourse that supports the traditional marriage. Although this conclusion might seem contradictory, it reminds us of what Widdowson asserts: "The discourse of the text... has to be accepted as contradictory"(42). 


\section{References}

Abjadian, Amrollah. $\quad \underline{\text { S Survey of English Literature }}$ .2vols.Tehran:SAMT,2002.

Barry, Peter. Beginning Theory: An Introduction to Literary and Cultural Theory. $3^{\text {rd }}$.ed. Manchester: Manchester UP,2009.

Bertens, Hans. Literary Theory: The Basics.London:Routledge, 2001.

Binion, Rudolph. "Fiction as Social Fantasy: Europe's Domestic Crisis of 1879-1914" Journal of Social History,27.No.4(1994) 679-99.

Bressler, Charles E. Literary Criticism: An Introduction to Theory and Practice.

$4^{\text {th }}$ ed.New Jersey:Pearson Prentice Hall,2007.

Butler, Lance St John. Studying Thomas Hardy.Essex: Longman York Press, 1989.

Fardad, M. "Marlow's Heroes: A Study of the Protagonists of His Major Plays in the

Light of New Historicism and Cultural Materialism" MA thesis .Allameh

Tabatabi U,1995.

Frawley, Maria. English Literature in Context. Ed. Paul Poplawski. Cambridge:

Cambridge UP,2008.

Gill, Richard. Mastering English Literature. $3^{\text {rd }}$ ed. Hampshire: Palgrave MacMillan,

2006.

Ingham, Patricia. Introduction. Jude the Obscure. By Thomas Hardy. Oxford: Oxford

UP,2002.

Lawrence, Karen, Betsy Seifter and Lois Ratner. The Macgraw Hill Guide to

English Literature. 2vols.New York:1985.

Lodge, David and Nigel Wood, eds. Modern Criticism and Theory: A Reader. $2^{\text {nd }} \mathrm{ed}$.

New York: Pearson Education,Inc.,2000. 
Matz, Aaron. "Terminal Satire and Jude the Obscure" ELH ;Summer 2006;73,2;

ProQuest Central.519-547.

Nemesvari, Richard. "Appropriating The Word: Jude the Obscure As Subversive

Apocrypha." Victorian Review 19(1993):48-66.

Stevenson, Lionel. Ed. Victorian Fiction: A Guide to Research .London: Oxford UP,

\section{4.}

Selden, Raman and Peter Widdowson. Contemporary Literary Theory .London:

Harvester Wheatsheaf ,1993.

Vance, Norman. Introduction. Jude the Obscure. By Thomas Hardy. London:

Wordsworth Classics, 1993.

Widdowson, Peter. Hardy in History: A Study in Literary Sociology. London:

Routledge, 1989.

Williams, Raymond. "Thomas Hardy." The Nineteenth -Century Novel: $\underline{\text { A Critical }}$

Reader .Ed. Stephen Regan. London: Routledge ,2001.363-73. Woolf, Virginia. "The Novels of Thomas Hardy." Victorian Literature

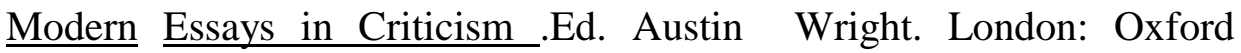
UP, 1961.172-81. 